CARVALHO, ADF; SILVA, GO; MAGALHÃES, CC. 2020. Yield and quality of carrot cultivars related to the harvest time. Horticultura Brasileira 38: 319-323. DOI - http://dx.doi.org/10.1590/S0102-053620200313

\title{
Yield and quality of carrot cultivars related to the harvest time
}

\author{
Agnaldo DF de Carvalho ${ }^{1 \mathbb{D}}$; Giovani O da Silva ${ }^{1} \mathbb{D}$; Caroline da C Magalhães ${ }^{2} \mathbb{D}$ \\ ${ }^{1}$ Embrapa Hortaliças, Brasília-DF, Brasil; agnaldo.carvalho@embrapa.br (author for correspondence); giovani.olegario@embrapa.br; ${ }^{2}$ Centro \\ Universitário de Desenvolvimento do Centro Oeste, Cidade Ocidental-GO, Brasil; carolinecruz.m@hotmail.com
}

\begin{abstract}
The knowledge about harvest time in carrots is important to determine the moment when the farmer will be able to obtain higher yield and quality of roots. Thus, this work aimed to verify the moment of harvest, aiming to maximize yield and the quality of roots. From November 2018 to March 2019, three cultivars, Brasília, BRS Planalto and HX4098 were evaluated in Brasília-DF in DBC design with three replications, in a split plot scheme, in which the treatments of the subplots were the harvest times at 80, 90, 100, 110 and 120 days after sowing (DAS). The experiment was installed on November 20,2018 , in $1 \mathrm{~m}^{2}$ useful area seedbeds. Sowing was done manually, in transverse grooves, with double spacing rows $10 \times 20 \mathrm{~cm}$, and 5 $\mathrm{cm}$ spacing between plants. Cultural treatments were those adopted for the carrot culture for the Brazilian Cerrado biome. At harvest, the total mass, non-commercial and commercial roots, number of roots of each class, average diameter and length of commercial roots and ${ }^{\circ}$ Brix were evaluated. The best harvest time to obtain maximum yield is close to $110 \mathrm{DAS}$, with a small reduction in ${ }^{\circ}$ Brix after $90 \mathrm{DAS}$.
\end{abstract}

Keywords: Daucus carota, root yield, ${ }^{\circ}$ Brix, root length, root diameter.

\section{RESUMO}

Produtividade e qualidade de cultivares de cenoura em função da época de colheita

O conhecimento sobre a época de colheita em cenoura é importante para determinar o momento em que o produtor poderá obter maiores produtividade e qualidade de raízes. Assim, este trabalho teve como objetivo verificar o momento da colheita, visando maximizar o rendimento e a qualidade de raízes. Entre novembro de 2018 a março de 2019, três cultivares, Brasília, BRS Planalto e HX4098 foram avaliadas em Brasília-DF em delineamentos DBC com três repetições, com esquema de parcela subdividida, em que os tratamentos das sub-parcelas foram as épocas de colheita aos 80 , $90,100,110$ e 120 dias após a semeadura (DAS). O experimento foi instalado em 20/11/2018, em canteiros de $1 \mathrm{~m}^{2}$ de área útil. A semeadura foi feita manualmente, em sulcos transversais, com espaçamento duplo de $10 \times 20 \mathrm{~cm}$, e espaçamento entre plantas de 5 $\mathrm{cm}$. Os tratos culturais foram os adotados para a cultura da cenoura para o cerrado brasileiro. Na colheita, foram avaliadas as massa total, do refugo e comercial de raízes, número de raízes de cada classe, diâmetro e comprimento médios de raízes comerciais e ${ }^{\circ}$ Brix. Verificou-se que a melhor época de colheita para obter o máximo rendimento é próximo aos $110 \mathrm{DAS}$, com pequena redução no ${ }^{\circ} \mathrm{Brix}$ a partir dos 90 DAS.

Palavras-chave: Daucus carota, rendimento de raízes, ${ }^{\circ}$ Brix, comprimento de raízes, diâmetro de raízes.

Received on October 9, 2019; accepted on June 9, 2020

$\mathrm{C}$ arrots are one of the main vegetables grown and consumed in Brazil. It is estimated that more than 480 thousand tons are produced annually in an area of more than 13 thousand ha. The main producing regions are Alto do Paranaíba Mineiro with more than $50 \%$ of the country's production, followed by the regions of Marilândia do Sul-PR, Caxias do Sul-RS, Cristalina-GO and Irecê-BA (IBGE, 2017).

The best time to harvest the carrot depends on the cultivar, sowing time and handling. Usually the harvest is carried out between 80 to 120 days after sowing (DAS) (Vieira et al., 2008), and this factor directly interferes in the productivity and quality of the carrot roots.

According to Kjellenberg et al. (2016), physiologically, the maturity of the carrot occurs when the carotenoids, as well as the sugars, reached their maximum concentrations. However, increasing the period from sowing to harvest, there is a tendency to increase root yield (Simões et al., 2010; Lana, 2012). This fact explains why producers delay harvests in order to increase productivity per unit area.

Sasaki (2015) proposed the classification of carrots in relation to root length in classes $10(\geq 10$ to $<14 \mathrm{~cm}), 14$ ( $\geq 14$ to $<18 \mathrm{~cm}), 18(\geq 18$ to $<22 \mathrm{~cm}$ ), 22 ( $\geq 22$ to $<26 \mathrm{~cm}$ ) and 26 $(>26 \mathrm{~cm})$. Being that farmers usually get the highest remuneration with the roots of class 18 ( $\geq 18$ to $<22 \mathrm{~cm})$ or "caixa $3 \mathrm{~A}$ ", as they better meet consumer preferences; while very small roots, below $10 \mathrm{~cm}$ in length, or very large, above $26 \mathrm{~cm}$ in length, are not desirable, as they are less valued by consumers (Silva et al., 2011).

In relation to other characteristics such as shape and appearance, the preference of Brazilian consumers is for roots with a diameter from three to five $\mathrm{cm}$, intense orange color and little differentiated between xylem and phloem, and without external defects 
such as cracks, forked or green/purple shoulder (Lana \& Vieira, 2000).

Regarding quality, a measure that is easy to evaluate, and that can be used in practice by farmers, is that of total soluble solids (Gomes Junior et al., 2001). When represented by ${ }^{\circ}$ Brix, the total soluble solids correspond to the percentage of solids dissolved in a solution. In fruits and vegetables, total soluble solids are predominantly composed of sugars, in addition to pectins, organic acids and amino acids, and these, by influencing flavor, become important quality factors (Magwara \& Opara, 2015). Studies show that total soluble solids can vary according to cultivar, fertilization, sowing density, irrigation, climate, and maturation stage (Lima Junior et al., 2012; Figueiredo Neto et al., 2010; Kleynhenz \& Bumgarner, 2012).

Thus, in this study we aimed to verify when the harvest should be carried out, aiming to maximize the yield and the quality of carrot roots.

\section{MATERIAL AND METHODS}

The experiment was carried out in the Embrapa Vegetable experimental area (15055'49"S; 4808'29"W, 1009 $\mathrm{m}$ altitude), located in Brasília-DF on November 28, 2018. In the period of the experiment, the average temperature was $22.21 \pm 0.56^{\circ} \mathrm{C}$ and total precipitation of $1,042 \mathrm{~mm}$. The region's climate is Aw, Tropical Climate with a dry season in winter, according to Köppen-Geiger. The soil in the experimental area is classified as a clayey Oxisol with a clay texture.

For sowing, the area was under fallow with carrot residues from the previous crop year, which were desiccated with non-selective herbicide (glyphosate in $2.85 \mathrm{~kg}$ a.i. ha ${ }^{-1}$ dosage) and incorporated in the plowing operation that occurred 60 days before sowing. One week before sowing, the soil was harrowed with a tandem disc and on the day of sowing the seedbeds were made with the bed shaper.

The soil analysis, performed three months before sowing, showed the following values: $\mathrm{pH}=6.0, \mathrm{P}=12.0$; $\mathrm{K}=399.0 ; \mathrm{Na}=41.0$, organic matter $=$
267.0; $\mathrm{B}=0.18 ; \mathrm{Cu}=3.30 ; \mathrm{Fe}=57.2$; $\mathrm{Mn}=69.7 ; \mathrm{Zn}=8.1$ and $\mathrm{S}=2.7$; all in $\mathrm{mg} \mathrm{dm}{ }^{-3}$, except $\mathrm{pH}$. Still $\mathrm{Ca}=3.3, \mathrm{Mg}=$ $1.5, \mathrm{Al}=0.0 ; \mathrm{H}+\mathrm{Al}=3.7$, all in cmolc $\mathrm{dm}^{-3}$. Thus, limestone was not applied, and fertilization was carried out based on soil analysis of the commercial formula 04-14-08 (NPK) in the amount of $1,300 \mathrm{~kg} \mathrm{ha}^{-1}\left(52 \mathrm{~kg} \mathrm{ha}^{-1} \mathrm{~N}, 182 \mathrm{~kg}\right.$ $\mathrm{ha}^{-1} \mathrm{P}_{2} \mathrm{O}_{5}$ and $104 \mathrm{~kg} \mathrm{ha}^{-1} \mathrm{~K}_{2} \mathrm{O}$ ) according to Ribeiro et al. (1999).

The experimental design was a randomized block with three replications in a $3 \times 5$ split plot scheme, in which the effects of cultivars were on the plots (Brasília, BRS Planalto and HX4098) and on the subplots, the effects of the harvest times $(80,90,100,110$ and 120 days after sowing, DAS). The experimental plot consisted of $1 \mathrm{~m}^{2}$ useful area.

Sowing was done manually in furrows across the bed, in double spacing $10 \times 20 \mathrm{~cm}$, with $10 \mathrm{~cm}$ between single rows and $20 \mathrm{~cm}$ between double rows, totaling a plant population of around 800 thousand plants per hectare after thinning. Weed control was carried out with the application of the herbicide linuron at $0.99 \mathrm{~L}$ of a.i. ha ${ }^{-1}$ four days after sowing. In the period after germination, weeding was performed manually.

Irrigation was carried out by conventional spraying, to meet the crop's demand in periods of scarcity of rain. The topdressing manuring was carried out right after thinning, at 30 DAS, in the dosage of $400 \mathrm{~kg} \mathrm{ha}^{-1}$ of ammonium sulfate $\left(80 \mathrm{~kg} \mathrm{ha}^{-1} \mathrm{~N}\right)$ according to Ribeiro et al. (1999).

From 60 DAS, weekly, the fungicide Difenoconazole was applied at a dose of $0.15 \mathrm{~kg}$ a.i. ha ${ }^{-1}$. The other handlings were those normally used for the cultivation of carrots in the Brazilian Cerrado region (Filgueira, 2008).

After each harvest, performed at 80 , 90, 100, 110 and 120 DAS, evaluations of the following characters were carried out: total root mass (TRM, $\mathrm{t} \mathrm{ha}^{-1}$ ), by weighing with digital scale all roots harvested in the plot; marketable root mass (MRM, $\mathrm{t} \mathrm{ha}^{-1}$ ), by weighing the roots with marketable standard; nonmarketable root mass (NRM, $\mathrm{t} \mathrm{ha}^{-1}$ ), obtained by the difference between
TRM and MRM; number of marketable roots (NMR, x $10^{3} \mathrm{ha}^{-1}$ ) by counting roots with marketable standard; number of total roots (NTR, ha-1 ${ }^{-1} 10^{3}$ ) by counting all roots harvested in the plot; number of non-marketable roots (NNR, $\mathrm{ha}^{-1} \times 10^{3}$ ) by the difference between NTR and NMR.

Roots without external defects such as cracks, forked or green shoulder were considered marketable; with a diameter between three and five $\mathrm{cm}$ and a length from 10 to $26 \mathrm{~cm}$. The conversion to hectare was calculated considering the effective width of the $1.5 \mathrm{~m} ; 1 \mathrm{~m}$ from the seedbed, plus $0.5 \mathrm{~m}$ from the spaces formed by the spaces between seedbeds.

Twenty marketable roots per plot were taken at random to obtain the average root diameter (ARD, measurements taken in the middle portion of the root, with a digital caliper, in $\mathrm{cm}$ ) and average root length (ARL, performed with a graduated ruler, in $\mathrm{cm})$. Then, a sample of approximately 20 grams of 20 roots from each plot was grated, mixed, and a drop of juice was removed to assess the content of total soluble solids using a digital refractometer (Atago Pocket) with results expressed in ${ }^{\circ}$ Brix.

The data were tested for the assumptions of the analysis of variance and the analyzes of variance were performed, as well the Tukey's means comparison test $(5 \%)$, and regression analyzes for the quantitative treatments (DAS). All analyzes were performed using the Genes computational application (Cruz, 2013).

\section{RESULTS AND DISCUSSION}

There were significant differences by the $\mathrm{F}$ test $(\mathrm{P}<0.05)$ between cultivars (C) and between harvest times (HT) for all characters. However, there were no significant differences in the $\mathrm{C} x$ HT interaction for any evaluated character (data not shown).

For total root mass (TRM), BRS Planalto $\left(65.69 \mathrm{t} \mathrm{ha}^{-1}\right)$ was superior to the hybrid HX $4098\left(56.57 \mathrm{tha}^{-1}\right)$ by the Tukey test at $5 \%$ probability, whereas 'Brasília' (57.22 $\left.\mathrm{t} \mathrm{ha}^{-1}\right)$ was not different from HX4098 and BRS Planalto (Table 1). For number of marketable roots 
(NMR) BRS Planalto (370.67 $\left.\times 10^{3} \mathrm{ha}^{-1}\right)$ and 'Brasília' (347.56 $\left.\times 10^{3} \mathrm{ha}^{-1}\right)$ were higher than HX4098 $\left(253.33 \times 10^{3} \mathrm{ha}^{-1}\right)$.

For marketable root mass (MRM) BRS Planalto (39.26 $\left.\mathrm{t} \mathrm{ha}^{-1}\right)$ was higher than 'Brasília' (31.14 $\mathrm{t} \mathrm{ha}^{-1}$ ), however HX4098 (34.69 $\mathrm{t} \mathrm{ha}^{-1}$ ) did not differ from BRS Planalto and 'Brasília'. For number of non-marketable roots (NNR) BRS Planalto $\left(278.39 \times 10^{3}\right.$ ha $\left.^{-1}\right)$ and 'Brasília' (300.87 x10 ha $\left.^{-1}\right)$ were higher than HX4098 (113.14 $\left.\mathrm{x} 10^{3} \mathrm{ha}^{-1}\right)$. There were no differences between the three cultivars for nonmarketable root mass (NRM), showing that although the hybrid HX 4098 had lower TRM than the open-pollinated cultivars, it presented MRM equivalent to BRS Planalto by the lowest NRM. As emphasized by Carvalho et al. (2015) and Pereira et al. (2015), the heterosis of carrot hybrids is due to the higher proportion of marketable roots, as these tend to have more uniform roots than open pollinated cultivars.

Regarding the two open pollination cultivars, Carvalho et al. (2015), measuring MRM at 100 DAS, found superior yield of commercial roots from BRS Planalto over Brasília, with values of 25.81 and $16.06 \mathrm{t} \mathrm{ha}^{-1}$, respectively. Likewise, Carvalho et al. (2017), in the evaluation in 20 environments, found an average MRM value of $34.54 \mathrm{t} \mathrm{ha}^{-1}$ for 'Brasília' and $35.95 \mathrm{t} \mathrm{ha}^{-1}$ for BRS Planalto. Pereira et al. (2015) evaluated the cultivar BRS Planalto in summer conditions in Brasília-DF, and found a high MRM (58.07 $\left.\mathrm{t} \mathrm{ha}^{-1}\right)$, roots with an average mass of $109.73 \mathrm{~g}$, with an average length of $17.43 \mathrm{~cm}$ and diameter of three $\mathrm{cm}$.

It is observed that in relation to ARL,
'Brasília' (18.47 cm) and 'BRS Planalto' $(18.41 \mathrm{~cm})$ presented greater length than 'HX4098' (17.25 cm), which, on the other hand, presents greater ARD (HX4098 $=3.26 \mathrm{~cm})$ if compared to 'Brasília' (3.03 cm) and 'BRS Planalto' $(3.08 \mathrm{~cm})$.

${ }^{\circ}$ Brix was superior for cultivar HX4098 (7.80) compared to 'Brasília' (6.93) and 'BRS Planalto' (6.53). This fact can be attributed to the possible genetic constitution of a hybrid, which probably has germplasm in its genealogy with a high degree of breeding for root quality (Carvalho et al., 2015).

Regarding ${ }^{\circ}$ Brix, several factors can influence the expression of this characteristic. In this sense, Alves et al. (2010) found a value of $8.63^{\circ}$ Brix for the cultivar Brasília harvested at 100 DAS, and Paulus et al. (2012), harvest at $85 \mathrm{DAS}$, found a value of $8.30^{\circ} \mathrm{Brix}$ also for 'Brasília'. Figueiredo Neto et al. (2010) found for this same cultivar, harvested at 92 DAS, an average value of $6.24^{\circ} \mathrm{Brix}$; with a variation of 5.53 to $7.20^{\circ}$ Brix depending on the type of fertilization used; and Lima Júnior et al. (2012) found significant effects of the interference of the amount of water used in irrigation at ${ }^{\circ}$ Brix.

The effects of harvesting times were represented using regression curves (Figures 1 and 2). For MRM it appears that the maximum yield was obtained around the harvest performed at 110 DAS, with 109 DAS for 'Brasília' (32.8 t ha $\left.{ }^{-1}\right), 111$ DAS for 'HX4098' (49.3 t $\left.\mathrm{ha}^{-1}\right)$ and 110 DAS for 'BRS Planalto' $\left(49.5 \mathrm{t} \mathrm{ha}^{-1}\right)$ (Figure 1A).

NMR decreased substantially with later harvests, until reaching their minimum in 120 DAS for 'Brasília'
(205 roots $\left.\times 10^{3} \mathrm{ha}^{-1}\right)$, in 107 DAS for 'HX4098' (203 roots x10 $\left.0^{3} \mathrm{ha}^{-1}\right)$ and 111 DAS for 'BRS Planalto' $\left(160\right.$ roots $\times 10^{3}$ ha $^{-1}$ ) (Figure 1B); and as the harvest time was delayed, the opposite was found for the NMR, with the highest values at 120 DAS for 'Brasília' (374 x10 $\left.0^{3} \mathrm{ha}^{-1}\right)$; earlier, at 104 DAS for 'HX4098', (378 $\mathrm{x} 10^{3} \mathrm{ha}^{-1}$ ); while for 'BRS Planalto' the largest NMR was achieved at 111 DAS (419 x10 ha $\left.^{-1}\right)$ (Figure 1D).

There was a greater increase for TRM between 90 and 110 DAS for the three cultivars, culminating in a higher value at 113 DAS for 'Brasília' (72.5 $\left.\mathrm{t} \mathrm{ha}^{-1}\right), 112$ DAS for 'HX4098' (81.0 t $\left.\mathrm{ha}^{-1}\right)$ and 111 DAS for 'BRS Planalto' $\left(74.5 \mathrm{t} \mathrm{ha}^{-1}\right)$ (Figure 1C).

NMR presented estimates of minimum values for 'Brasília' $(9.1 \mathrm{t}$ ha $\left.^{-1}\right)$ ' 'HX4098' (11.7 t ha ${ }^{-1}$ ) and 'BRS Planalto' $\left(22.6 \mathrm{t} \mathrm{ha}^{-1}\right)$, for harvests at 89 , 87 and 94 DAS, respectively (Figure 2A).

The increase in MRM with the advance in the cycle is also reported by Lana (2012), in the evaluation of spacing and harvest times in carrots for the production of baby carrots.

On the other hand, the ARL increased until reaching the maximum at $109 \mathrm{DAS}$ for 'HX4098' $(16.91 \mathrm{~cm}), 106$ DAS for 'Brasília' (19.16 cm), and at 95 DAS for 'BRS Planalto' (17.85 cm). The ARD, however, decreased after about 100 DAS, since, after that period, a larger amount of roots with a larger diameter began to present defects such as cracks, rot, deformation, green/purple shoulder, withered or injured roots by the pest attack, with a $13 \%$ increase in losses (data not shown), predominantly due to the disposal of very thick roots.

Table 1. Tukey's means test between three carrot cultivars, averaging different harvest periods (80, 90, 100, 110 and 120 days after sowing). Brasília, Embrapa Hortaliças, 2019.

\begin{tabular}{lllllllll}
\hline Cultivars & TRM & NMR & MRM & NNR & NRM & ARL & ARD & ${ }^{\mathbf{0} B r i x}$ \\
\hline BRS Planalto & $65.69 \mathrm{a}$ & $370.67 \mathrm{a}$ & $39.26 \mathrm{a}$ & $278.39 \mathrm{a}$ & $25.40 \mathrm{a}$ & $18.41 \mathrm{a}$ & $3.08 \mathrm{~b}$ & $6.53 \mathrm{~b}$ \\
Brasília & $57.22 \mathrm{ab}$ & $347.56 \mathrm{a}$ & $31.14 \mathrm{~b}$ & $300.87 \mathrm{a}$ & $23.66 \mathrm{a}$ & $18.47 \mathrm{a}$ & $3.03 \mathrm{~b}$ & $6.93 \mathrm{~b}$ \\
HX-4098 & $56.57 \mathrm{~b}$ & $253.33 \mathrm{~b}$ & $34.69 \mathrm{ab}$ & $113.14 \mathrm{~b}$ & $20.12 \mathrm{a}$ & $17.25 \mathrm{~b}$ & $3.26 \mathrm{a}$ & $7.80 \mathrm{a}$ \\
\hline Means & 59.83 & 323.85 & 35.03 & 230.80 & 23.06 & 18.05 & 3.12 & 7.09 \\
CV (\%) & 16.08 & 20.02 & 10.20 & 12.97 & 16.16 & 5.50 & 3.51 & 8.17 \\
\hline
\end{tabular}

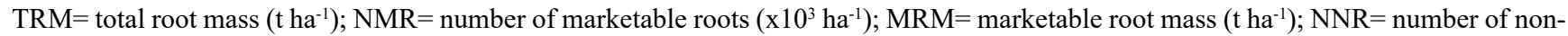
marketable roots $\left(\mathrm{x}^{3} 0^{3} \mathrm{ha}^{-1}\right) ; \mathrm{NRM}=$ non-marketable root mass $\left(\mathrm{t} \mathrm{ha}^{-1}\right) ; \mathrm{ARL}=$ Average root length $(\mathrm{cm})$; $\mathrm{ARD}=$ average root diameter $(\mathrm{cm})$. Means followed by different letters in the columns differed statistically by the Tukey test at $5 \%$. 
In the literature, the increase in yield at the end of the cycle occurs mainly due to the increase in the diameter of the roots, and not so much in length (Simões et al., 2010; Vieira et al., 2012). Due to the fact that the roots initially develop more in length, with later greater growth in diameter (Silva et al., 2009; Vieira et al., 2012), however this fact cannot be standardized for ARD, in which the delay in harvesting considerably increases the number of thick roots discarded by serious defects.

Total soluble solids, represented by ${ }^{\circ}$ Brix, were highest at 91 days for 'Brasília' (6.6 ${ }^{\circ}$ Brix), at 89 days for 'HX4098' (7.2 ${ }^{\circ}$ Brix) and 91 days for 'BRS Planalto' (6.4 ${ }^{\circ}$ Brix) (Figure 2C).

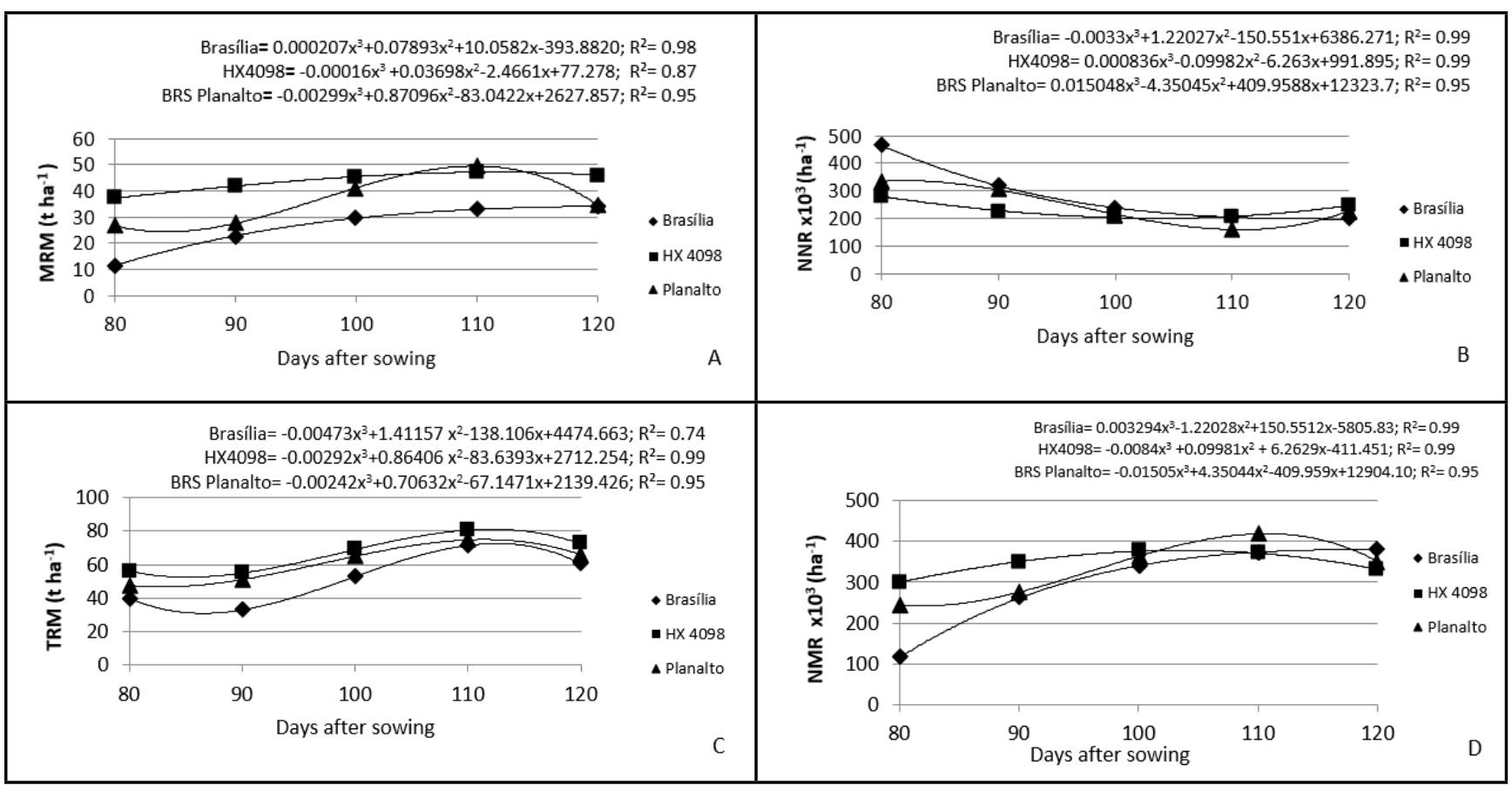

Figure 1. Regression analysis for three carrot cultivars evaluated for marketable root mass (MRM), number of non-marketable roots (NNR); total root mass (TRM) and number of marketable roots (NMR) due to different harvest times in the Federal District. Brasília, Embrapa Hortaliças, 2019.

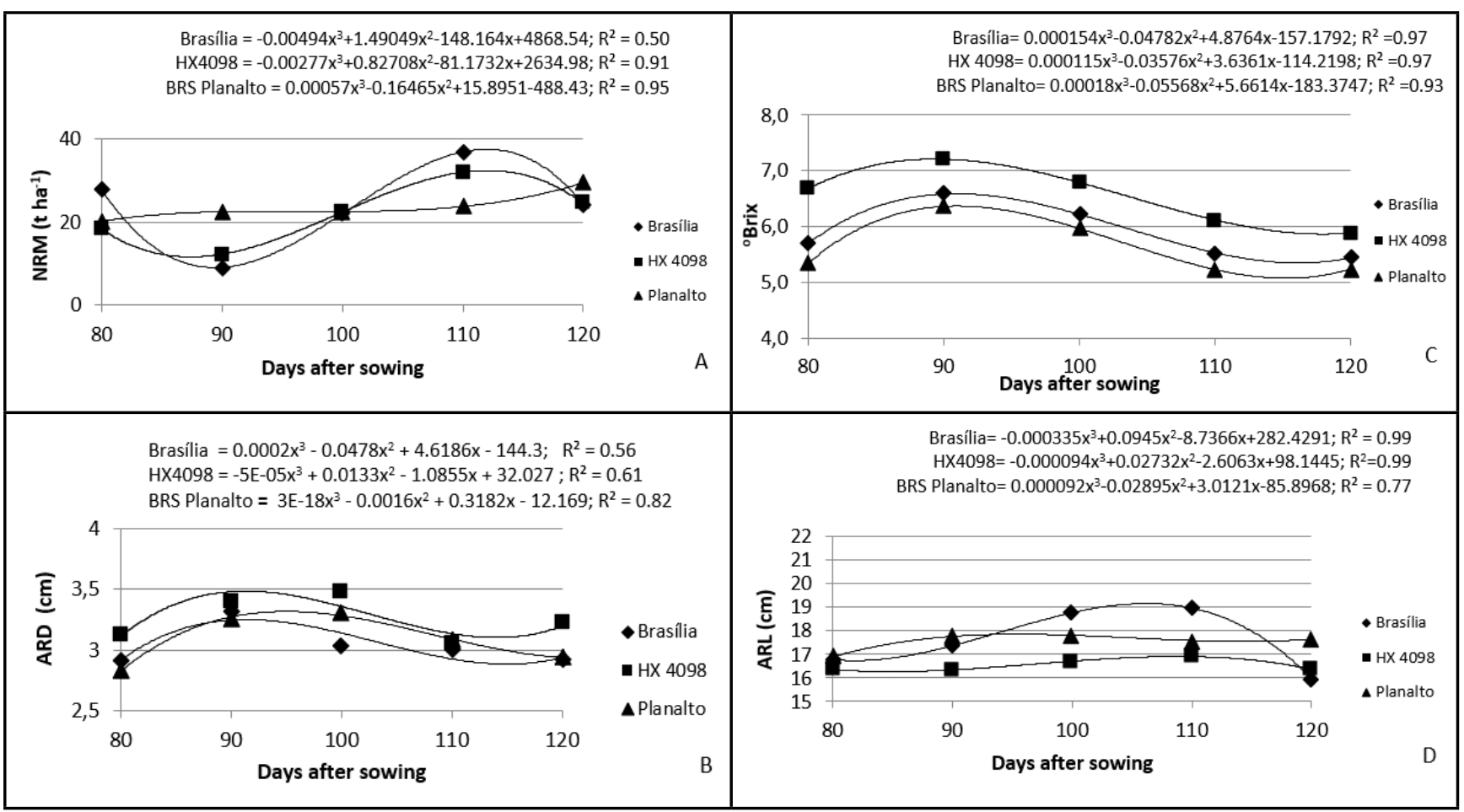

Figure 2. Regression analysis for three carrot cultivars evaluated for non-marketable root mass (NRM), average root diameter (ARD), ${ }^{\circ}$ Brix and average root length (ARL) due to different harvest times in the Federal District. Brasília, Embrapa Hortaliças, 2019. 
Therefore, there is an indication that in this period the roots had the best quality in relation to the sugar content, and that this value decreased too much with the delay in the harvest period.

About TSS, the peak concentration coincides with the accumulation curve for this compound described by Rubatzky et al. (1999). The change in the total sugar content after 90 DAS, with a reduction after this period, can occur, among other factors, by the reduction of the leaf area after this period, which affected the production and accumulation of secondary compounds, such as sugars. Another factor that may have contributed to this reduction in ${ }^{\circ}$ Brix levels may be the increase in the values of the component production characters (MRT, MRC and MRR) after 90 DAS, with the plants entering the senescence stage, resulting in a greater accumulation of fresh mass at the expense of ${ }^{\circ}$ Brix levels.

In assessing the accumulation of dry matter from 50 DAS, Simões et al. (2010) found that there were no significant differences for the cultivar Forto with the harvest time from 50 DAS to 106 DAS, that is, in periods closer to harvest, the ${ }^{\circ} \mathrm{Brix}$ content remains constant, despite the increasing root size. Gajewski et al. (2009) evaluating eight carrot cultivars in Poland, with cultivars suitable for that country, described increasing values of ${ }^{\circ}$ Brix with successive harvest periods ranging from 40 to $125 \mathrm{DAS}$. In view of these results, it was found that the best harvest time to maximize the yield of commercial roots, both for the open pollination cultivars 'BRS Planalto' and 'Brasília', and for the hybrid 'HX4098', is around $110 \mathrm{DAS}$, although there is a small reduction in the ${ }^{\circ}$ Brix content after 90 DAS.

\section{REFERENCES}

ALVES, SSV; NEGREIROS, MZ; AROUCHA, EMM; SILVA TEÓFILO, TM; FREITAS, FCL; SOUSA NUNES, GH; LOPES, WDAR.
2010. Qualidade de cenouras em diferentes densidades populacionais. Revista Ceres 57: 218-223.

CARVALHO, ADF; SILVA, GO; PEREIRA, RB; PINHEIRO, JB. 2015. Produtividade e tolerância à queima-das-folhas de diferentes genótipos de cenoura de verão. Horticultura Brasileira 33: 299-304.

CARVALHO, ADF; SILVA, GO; RESENDE, FV. 2017. Adaptabilidade e estabilidade de populações de cenoura pelo método REML/ BLUP. Horticultura Brasileira 35: 069-074.

CRUZ, CD. 2013. Genes: a software package for analysis in experimental statistics and quantitative genetics. Acta Scientiarum Agronomy 35: 271-276.

LIMA JUNIOR, JA; SILVA, ALP; GUEDES, MGM. 2012. Qualidade de raízes de cenouras em função de diferentes tensões da água no solo. Engenharia Ambiental 9: 26-35.

FIGUEIREDO NETO, A; OLIVEIRA, SB; SANTOS LIMA, M; ROCHA AMORIM, M; FIGUEIREDO, RMC. 2010. Efeito do composto orgânico nas características físicoquímicas de cenoura "Brasília". Revista Brasileira de Produtos Agroindustriais 12: 61-66.

FILGUEIRA, FAR. 2008. Novo manual de olericultura: Agrotecnologia moderna na produção e comercialização de hortaliças. Viçosa: UFV. 412p.

GAJEWSKI, M; SZYMCZAK, P; BAJER, M. 2009. The accumulation of chemical compounds in storage roots by carrots of different cultivars during vegetation period. Acta Scientiarum Polonorum Hortorum Cultus 8: 69-78.

GOMES JUNIOR, J; MENEZES, JB; NUNES, GHS; COSTA, FB; SOUZA, PA. 2001. Qualidade pós-colheita do melão tipo cantaloupe, colhido em dois estádios de maturação. Horticultura Brasileira 19: 223227.

INSTITUTO BRASILEIRO DE GEOGRAFIA E ESTATÍSTICA - IBGE. 2017. Horticultura: número de estabelecimentos agropecuários e quantidade produzida por produtos da horticultura. Available at: <https://sidra.ibge. gov.br/tabela/6619\#resultado $>$ Accessed August 23, 2019.

KJELLENBERG LJE; GUSTAVSSON K; GRANSTEDT A; OLSSON M. 2016. Influence of organic manures on carrot (Daucus carota L.) crops grown in a longterm field experiment in Sweden. Renewable Agriculture and Food Systems 31: 258-268.

KLEYNHENZ, MD; BUMGARNER, NR. 2012. Using ${ }^{\circ}$ Brix as an indicator of vegetable quality. Fact Sheet Agriculture and Natural Resources. The Ohio State University Extension, 4p.

LANA, MM; VIEIRA, JV. 2000. Fisiologia e manuseio pós-colheita de cenoura. Brasília: Embrapa. 15p. (Circular Técnica 21)

LANA, MM. 2012. The effects of line spacing and harvest time on processing yield and root size of carrot for Cenourete ${ }^{\circledR}$ production. Horticultura Brasileira 30: 304-311.

MAGWARA LS; OPARA. 2015. Analytical methods for determination of sugars and sweetness of horticultural products - a review. Scientia Horticulturae 184: 179-192.

PAULUS, D; MOURA, CA; SANTIN, A; DALHEM, AR; NAVA, GA; RAMOS, CEP. 2012. Produção e aceitabilidade de cenoura sob cultivo orgânico no inverno e no verão. Horticultura Brasileira 30: 446-452.

PEREIRA, RB; CARVALHO, ADF; PINHEIRO, JB; SILVA, GO; VIEIRA, JV. 2015. Avaliação de híbridos experimentais de cenoura no Distrito Federal. Horticultura Brasileira 33: 34-39.

RIBEIRO, AC; ALVAREZ, VVH; GUIMARÃES, PTG. 1999. Recomendações para o uso de corretivos e fertilizantes em Minas Gerais - $5^{a}$ Aproximação. Viçosa: Comissão de Fertilidade do Solo do Estado de Minas Gerais. 359p.

RUBATZKY, VE; QUIROS, CF; SIMON, PW. 1999. Carrots and related vegetable Umbelliferae. Crop Production Science in Horticulture. Wallingford: CABI Publishing, CAB International, 294p.

SASAKI, ET. 2015. Ficha da cenoura. CEAGESP. Companhia de Entrepostos e Armazéns Gerais de São Paulo. Available at <http://www. ceagesp.gov.br/wp-content/uploads/2015/07/ cenoura.pdf $>$ : Accessed August 13, 2019.

SILVA, GO; VIEIRA, JV; VILELA, MS. 2009. Seleção de caracteres de cenoura cultivada em dois sistemas de produção agroecológicos no Distrito Federal. Revista Ceres 56: 595-601.

SILVA, VJ; TEODORO, REF; CARVALHO, HP; MARTINS, AD; LUZ, JMQ. 2011. Resposta da cenoura à aplicação de diferentes lâminas de irrigação. Bioscience Journal, 27: 954-963

SIMÕES, AN; MOREIRA, SI; COSTA, FB; ALMEIDA, AR; SANTOS, RHS; PUSCHMANN, R. 2010. Populational density and harvest age of carrots for baby carrot manufacture. Horticultura Brasileira 28: $147-154$.

VIEIRA, JV; SILVA, GO; BOITEUX, LS. 2012. Genetic parameter and correlation estimates of processing traits in half-sib progenies of tropical-adapted carrot germplasm. Horticultura Brasileira 30: 7-11.

VIEIRA, JV; PESSOA, HBSV; MAKISHIMA, N. 2008. Cenoura (Daucus carota). Embrapa Hortaliças. Available at $<$ https:// sistemasdeproducao.cnptia.embrapa.br/ FontesHTML/Cenoura/Cenoura_Daucus_ Carota/colheita.html $>$ Accessed August 13, 2019. 